\title{
DESAIN PROTOKOL SUARA SEBAGAI PENGENDALI DALAM SMART HOME MENGGUNAKAN FPGA
}

\author{
Barlian Henryranu Prasetio ${ }^{1}$, Dahnial Syauqy ${ }^{2}$ \\ ${ }^{1,2}$ Fakultas Ilmu Komputer, Universitas Brawijaya \\ Email: ${ }^{1}$ barlian@ub.ac.id, dahnial87@ub.ac.id ${ }^{2}$
}

(Naskah masuk: 9 Maret 2017, diterima untuk diterbitkan: 7 Mei 2017)

\begin{abstract}
Abstrak
Smart home adalah suatu sistem yang menggunakan komputer dan teknologi informasi untuk mengendalikan peralatan yang terdapat di rumah seperti jendela dan lampu. Sistem dapat berupa sistem control sederhana hingga sistem yang kompleks. Komputer/mikrokontroler yang berbasis jaringan internet/ethernet dilengkapi dengan sistem cerdas dan sistem otomasi sehingga mampu membuat rumah menjadi bekerja secara otomatis. Banyak perangkat komputer/mikrokontroler yang dapat diimplementasikan sebagai pengendali dalam smart home. Sistem pengendali smart home pada penelitian ini menggunakan Xilinx xpartan-3e yang mengendalikan peralatan dalam rumah melalui jaringan LAN (Local Area Networking). Sistem pengendali ini berkomunkasi menggunakan broadcast voice pada jaringan lokal. Sistem Pengendali ini dirancang untuk dapat mengirimkan paket sinyal suara (voice) dari masukan microphone dan kemudian mengirimnya menggunakan protokol ethernet dalam jaringan lokal rumah menggunakan FPGA. FPGA ini diprogram untuk mengirimkan dan mengkodekan paket data, mengkonversi data digital menjadi data analog untuk dapat mengendalikan peralatan dalam rumah. Dari hasil pengujian simulasi menggunakan ISim, terlihat bahawa sistem bekerja secara realtime.
\end{abstract}

Kata kunci: smart home, suara, FPGA, pengendalian

\begin{abstract}
Smart home is a system that uses computers and information technology to control home-like equipment such as windows and lights. The system can be a simple control system to a complex system. Computer / microcontroller based on internet/ethernet network equipped with intelligent system and automation system so as to make home to work automatically. Many computer devices / microcontrollers that can be implemented as a controller in the smart home. Smart home control system in this study using Xilinx xpartan-3e that controls the equipment in the house through LAN (Local Area Networking). This control system communicates using broadcast voice on the local network. The Controller System is designed to be able to transmit a voice signal packet from the microphone input and then send it using the ethernet protocol in the home local network using the FPGA. The FPGA is programmed to transmit and encode data packets, converting digital data into analog data to be able to control the equipment in the home. From the simulation test results using ISIM, it is seen that the system works in realtime.
\end{abstract}

Keywords: smart home, voice, FPGA, control

\section{PENDAHULUAN}

Smart home yang sering disebut sebagai rumah pintar atau eHome adalah suatu rumah yang memiliki sistem otomatis yang sangat canggih untuk mengontrol peralatan rumah seperti pencahayaan dan suhu, peralatan multi-media, memantau dan mengaktifkan alarm serta membuka dan menutup jendela atau pintu dan banyak fungsi lainnya. Sebuah rumah pintar tampak "cerdas" karena sistem komputer yang dapat memantau banyak aspek kehidupan sehari-hari. Misalnya, sebuah lemari es yang dapat mengisi persediaannya sendiri, menyarankan menu, merekomendasikan alternatif yang sehat, dan memesan makanan. Sistem rumah pintar bahkan mungkin mengurus membersihkan kotak sampah kucing dan menyiram tanaman (Bregman D, 2010).

Hampir semua sistem smart home terhubung ke sebuah komputer server, sehingga komputer menjadi sistem monitor dan kendali yang terpusat. Sistem ini biasanya dibekali dengan sistem keamanan berupa sistem autentifikasi username dan password (Arifiyanto F etal, 2014). Dengan sistem yang terpusat, pengendalian sistem menjadi lebih efisien dan mudah. Namun jika ditinjau dari segi keamanan, sistem terpusat akan menjadi suatu kelemahan. Sistem autentikasi username dan password menjadi sistem autentifikasi yang rawan terbongkar. Sistem autentikasi smart home menggunakan keunikan manusia (suara) akan menjadi gerbang pengendali dalam komunikasi teknologi konvergen. 
Jika kita tinjau dari sisi infrastruktur dari sistem yang kompleks akan membutuhkan infrastruktur yang banyak dan mahal. Sebenarnya kebutuhan infrastruktur untuk sistem komunikasi/informasi ini hanya membutuhkan koneksi antar komputer. Namun pada penelitian yang pernah dilakukan, implementasi secara nyata menjadi tidak praktis dan cukup mahal karena harus membeli banyak komputer untuk penerima audio yang bersifat tidak real-time. Sebuah perangkat alternatif yang dapat digunakan untuk menerima paket suara dan pengendali audio eksternal (speaker) adalah Field Programmable Gate Array (FPGA) (Perkins C, 2003). FPGA lebih murah dibandingkan dengan komputer dan hemat daya dan mampu bekerja secara real time (fpga4fun, 2014). Selain itu, dengan menggunakan FPGA untuk menerima dan mengendalikan speaker akan memungkinkan sistem ini bekerja secara independen menggunakan sisa bandwidth jaringan utama (Xilinx, 2011).

Penelitian ini, bertujuan untuk mendesain sistem komunikasi/informasi berbasis Ethernet dengan menggunakan PC dan FPGA Xilinx Spartan-3E. Dengan menggunakan PC pada bagian input dan FPGA bagian penerima, penelitian ini diharapkan akan mampu menunjukkan prinsip-prinsip komunikasi data (VoIP) dan menjelaskan pemahaman perangkat lunak dan perangkat keras yang diimplementasikan sebagai aplikasi embedded sistem untuk komunikasi data. Jaringan menggunakan Ethernet 802.3 standar (IEEE, 2012) yang memungkinkan banyak host untuk mengirim dan menerima data melalui jaringan twisted pair. Penelitian ini memiliki tiga bagian: server/transmitter (PC), backbone LAN, dan penerima (FPGA).

\section{BLOK DIAGRAM SISTEM}

Pada bagian pengendali, sistem ini menggunakan komputer pribadi (PC) yang terhubung ke Local Area Network yang berfungsi sebagai server pusat. Sebuah mikrofon, terhubung ke jack mikrofon dari audio card PC (on board) berfungsi sebagai input. Modul ini menampilkan informasi seperti nama host dari server PC, alamat IP, port dan alamat tujuan (Cisco, 2001) dan total ukuran buffer. FPGA terhubung ke LAN melalui konektor RJ45 (fpga4fun, 2013), bertindak sebagai penerima. FPGA ini akan menghasilkan suara yang nantinya akan berfungsi sebagai pengendali peralatan yang berada dalam rumah. Blok diagram sistem secara keseluruhan dapat dilihat pada gambar 1 .

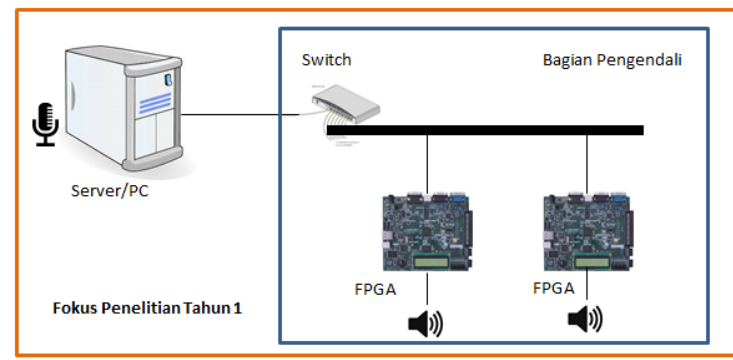

Gambar 1. Blok Diagram Sistem

\section{METODE PENELITIAN}

Paket data suara dikirim pada modul pengendali melalui konektor RJ45 onboard. Modul ini dibagi menjadi empat bagian seperti yang ditunjukkan pada Gambar 2: SFD (Frame Starter), AM (Address Matching), Buffer, dan DAC (Digital Analog Converter).

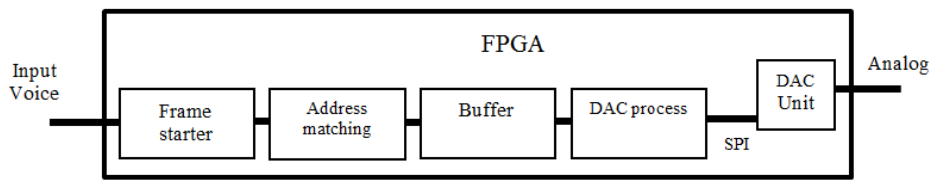

Gambar 2. Blok Diagram Modul Pengendali

Paket data diterima melalui konektor RJ45. Setelah diterima, modul pengendali akan memeriksa apakah data tersebut valid atau tidak. Jika valid, maka akan mengaktifkan FS.

FS mendeteksi start bit pada frame ethernet. paket ethernet terdiri dari 7 bit. Menurut standar ethernet 802.3, LSB dikirim terlebih dahulu. Untuk memastikan fungsi ini berjalan maka diberikan sebuah counter yang menhitung sebanyak 7 siklus. Setelah FS mendeteksi paket data telah terkirim semua, maka FS mengaktifkan AM.

AM memeriksa apakah informasi paket ditujukan pada modul pengendali. Pencocokan alamt pengirim meliputi alamat MAC, tipe ethernet, jenis protokol, alamat IP dan alamat port. Jika informasi cocok, Buffer menyimpan data dalam paket. Buffer menerima data setiap 4 bit tiap silkus clock sehingga membutuhkan 2 siklus untuk dapat menyimpan data dalam 1 blok RAM. Proses ini berlanjut sampai counter mencapai batas tertentu. Setelah counter mencapai batas tersebut, maka buffer berubah status menjadi disable dan mengaktifkan DAC.

Setelah data disimpan, DAC mengubah data digital menjadi analog untuk memicu speaker eksternal untuk dapat menghasilkan sinyal suara analog. Pseudocode modul FPGA ditunjukkan pada code 1 .

Code 1. Pseudocode Modul Pengendali

FS CODE
if STATE_FS $=$ ' 1 ' then
if RX_DATA $=$ "1010" then
COUNT_FS $<=$ COUNT_FS +1 ;
elsif RX_DATA $=$ "1011" then




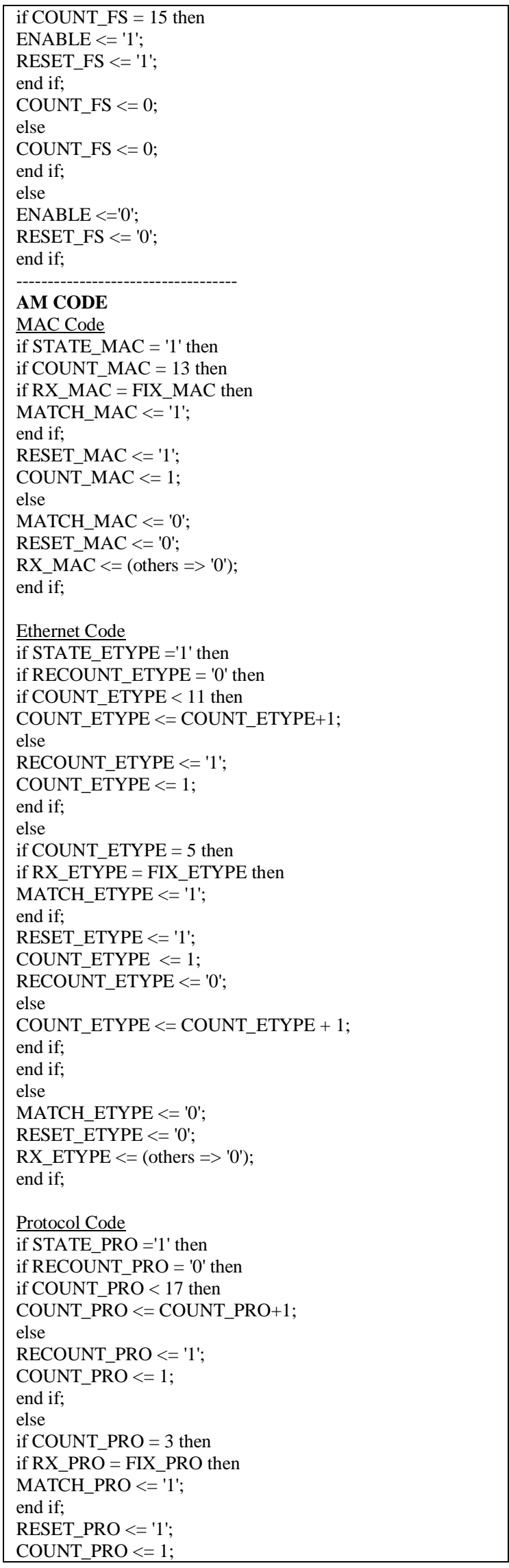

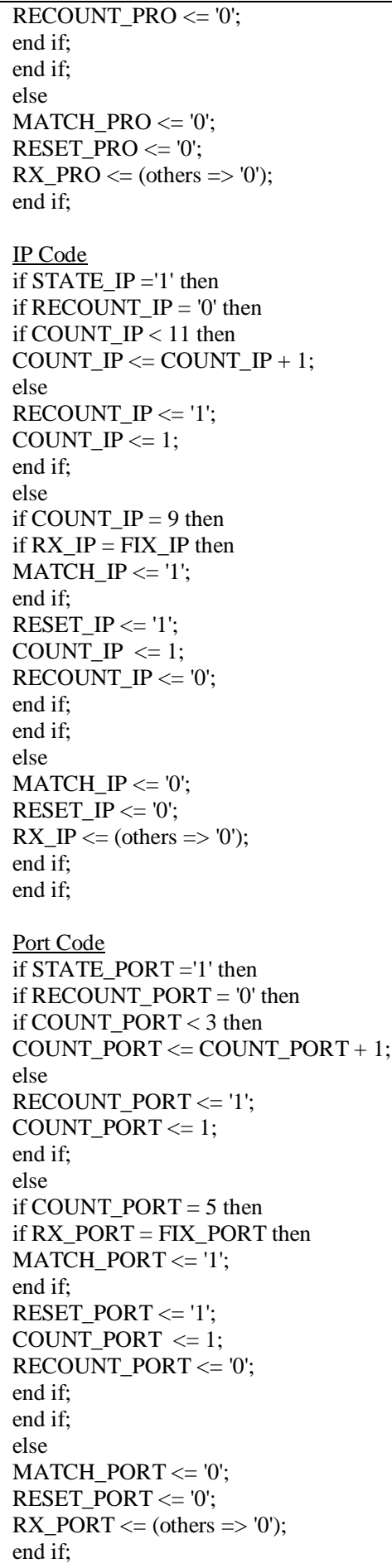

\section{HASIL DAN PEMBAHASAN}

Modul Pengendali dibangun menggunakan Xilinx Spartan-3E dan diprogram dalam VHDL menggunakan Xilinx ISE 8.2i. Rangkaian RTL modul FPGA ditunjukkan pada gambar 4. 


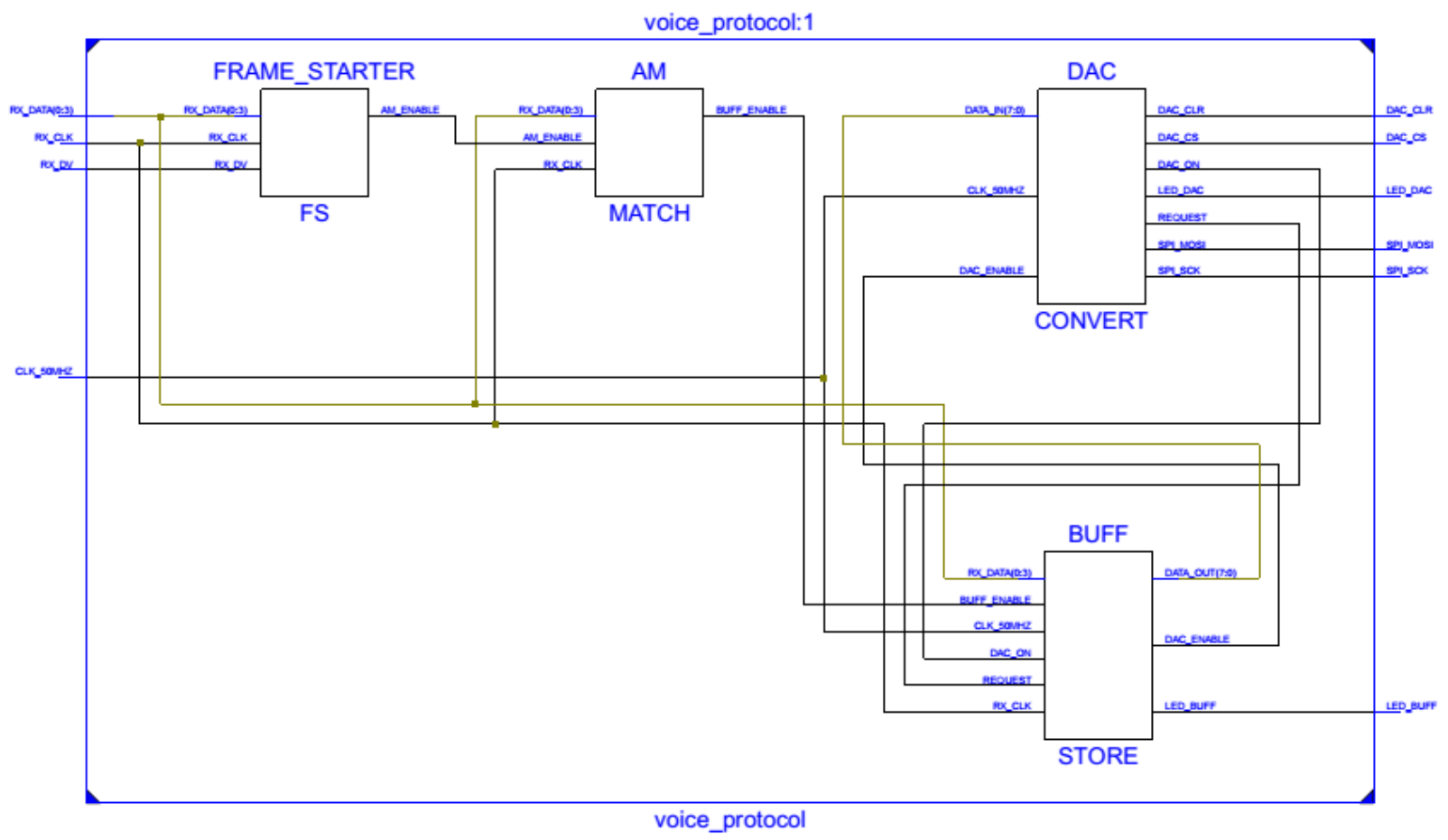

Gambar 4. Rangkaian RTL Modul Pengendali

Gambar 4 menunjukkan bahwa sistem terdiri atas frame starter (FS), Address Matching (AM), Buffer (BUFF) and Digital to Analog Converter (DAC). Deskripsi RTL Schematics dapat dilihat pada table 1 sedangkan rangkuman penggunaan FPGA ditunjukkan pada table 2 .

Tabel 1 Deskripsi RTL Schematics

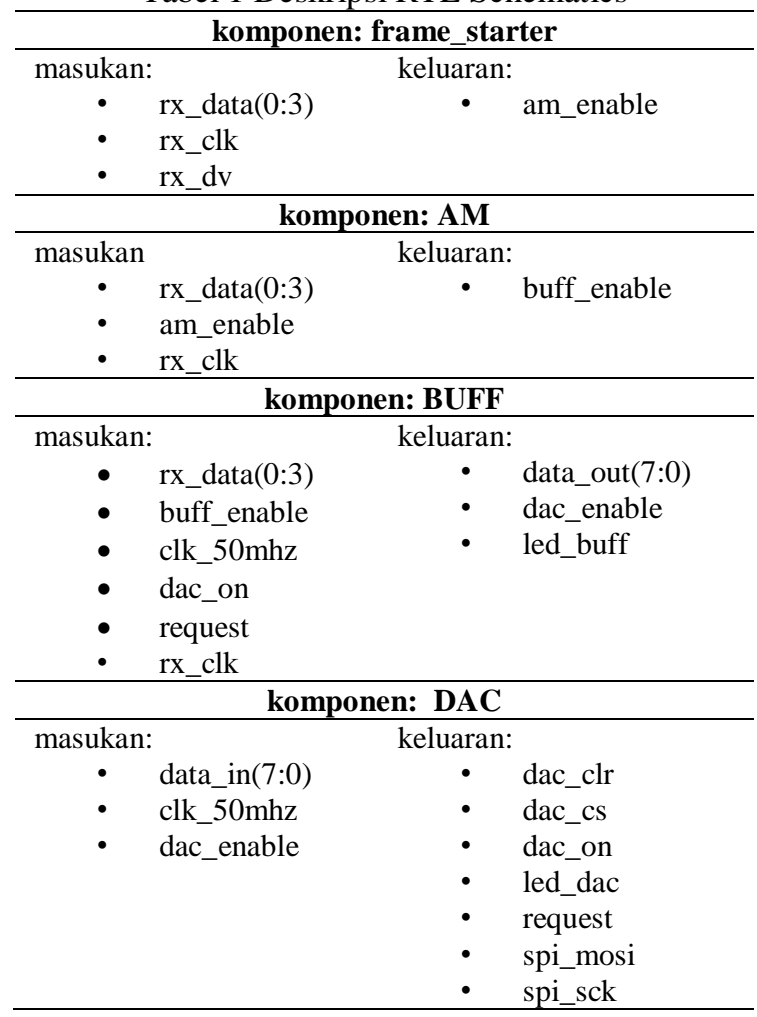

penggunaan logika digunakan tersedia penggunaan

\begin{tabular}{lccc}
\hline $\begin{array}{l}\text { jumlah flip-flop } \\
\text { jumlah luts } 4\end{array}$ & 485 & 9,312 & $5 \%$ \\
$\begin{array}{l}\text { masukan } \\
\text { jumlah slice yang } \\
\text { digunakan }\end{array}$ & 683 & 9,312 & $7 \%$ \\
$\begin{array}{l}\text { total jumlah luts } 4 \\
\text { masukan }\end{array}$ & 929 & 9,656 & $12 \%$ \\
$\begin{array}{l}\text { jumlah ramb16s } \\
\text { jumlah bufgmuxs }\end{array}$ & 16 & 20 & $80 \%$ \\
\hline
\end{tabular}

Program VHDL di simulasikan pada ISim (O.87xd). Simulasi ISim ditunjukkan pada gambar 5 .

Tabel 2. Rangkuman Penggunaan FPGA 

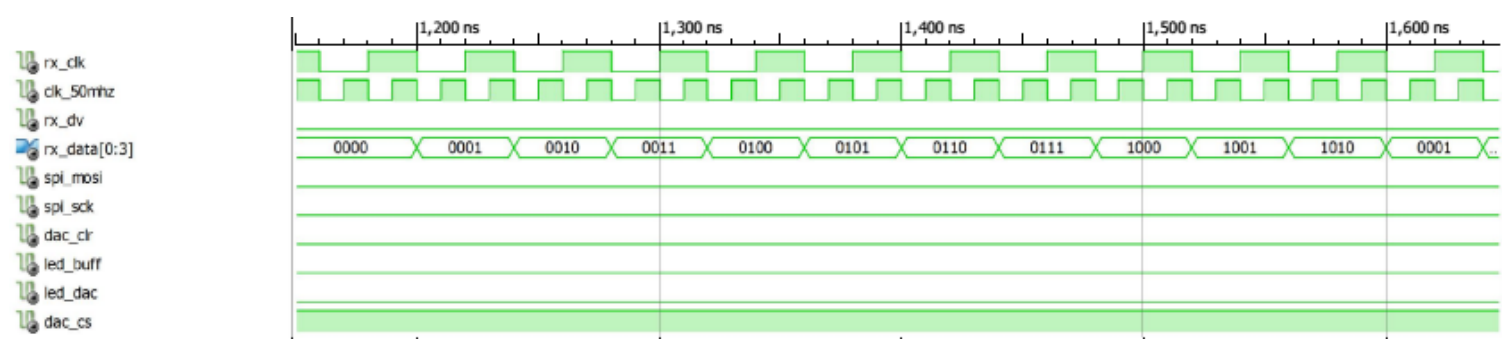

Gambar 5. Simulasi Sistem keseluruhan menggunakan ISim

\section{KESIMPULAN}

Sistem smart home ini berbasis suara melalui Ethernet. Sistem menggunakan PC sebagai server dan Xilinx Spartan-3E sebagai penerima. Sistem mengirimkan sinyal audio dari PC melalui LAN ke FPGA dan mereproduksi sinyal menggunakan speaker audio eksternal. Berdasarkan pengujian yang dilakukan pada sistem, suara dapat berhasil dikirim ke FPGA. Dari hasil pengujian simulasi menggunakan ISim, terlihat bahawa sistem bekerja secara realtime. Selain itu, menurut device utilization dapat dilihat prosentase penggunaan memori terlihat cukup besar yakni mencapai $80 \%$.

\section{DAFTAR PUSTAKA}

ARIFIYANTO F ETAL, 2014, Perancangan Prototype Web-Based Online Smart Home Controlled By Smartphone, Jurusan Teknik Elektro, Fakultas Teknik, Universitas Diponegoro.
BREGMAN D, 2010, Smart Home Intelligence The eHome that Learns, International Journal of Smart Home, Vol.4, No.4.

CISCO, 2001, IP Multicast Technology Overview, http://www.cisco.com/c/en/us/td/docs/ios/soluti ons_docs/ip_multicast/White_papers/mcst_ovr. html\#wp1009849

FPGA4FUN, 2013, How Ethernet works, http://www.fpga4fun.com/10BASE-T1.html

FPGA4FUN, 2014, Receiving Packets, http://www.fpga4fun.com/10BASE-T4.html

IEEE, 2012, IEEE Standard for Ethernet, IEEE Computer Society

PERKINS C, 2003, RTP Audio and Video for the Internet, Addison Wesley

XILINX, 2011, Spartan-3E Starter Kit Board User Guide, UG230 (v1.0), www.xilinx.com/support/documentation/board s_and_kits/ug230.pdf 